\title{
Pengaruh Sistem Pengelolaan Dana Desa Terhadap Laporan Keuangan Desa Tua Marga Tabanan
}

\author{
I Gusti Putu Geria Warsita W., Ni Luh Prasetiani Agustini, Ni Kadek Ayu Widia, \\ Ni Nyoman Dewi Diah Kumalawati \\ Jurusan Akuntansi, Universitas Pendidikan Ganesha, Singaraja, Bali, Indonesia
}

\begin{abstract}
Abstrak
Penelitian ini bertujuan untuk mengetahui pengertian dari dana desa, bagaimana cara dana desa di kelola oleh pemerintah desa, dan bagaimana pengaruh sistem pengelolaan dana desa terhadap laporan keuangan Desa. Metode penelitian yang digunakan yaitu metode kualitatif dengan cara wawancara dan observasi. Sistem pengelolaan dana desa akan berpengaruh pada laporan keuangan desa. Dalam hal ini system pengelolaan dana desa pada Desa Tua Kabupaten Tabanan yang mulai beralih dari basis kas menuju basis akrual. Sistem pengelolaan dana desa pada Desa Tua dengan menggunakan basis kas masih banyak terdapat masalah-masalah pada laporan keuangannya. Dengan beralih menuju basis akrual diharapkan masalahmasalah tersebut dapat teratasi.
\end{abstract}

Kata Kunci : Pengelolaan, Dana, Laporan Keuangan

\begin{abstract}
This study aims to determine the understanding of village funds, how village funds are managed by the village government, and how the influence of the village fund management system on village financial reports. The research method used is a qualitative method by interview and observation. The village fund management system will affect village financial reports. In this case the village fund management system in Desa Tua Tabanan Regency is starting to shift from the cash basis to the accrual basis. The village fund management system in Desa Tua using a cash basis there are still many problems with the financial statements. By switching to the accrual basis it is hoped that these problems can be overcome.
\end{abstract}

Keywords: Management, Funds, Financial Statements

\section{Pendahuluan}

Negara Kesatuan Republik Indonesia telah mengatur keberadaan desa dalam Undang-Undang No 22 Tahun 1999 yang telah direvisi melalui UndangUndang No 32 Tahun 2004 tentang Pemerintahan Desa. Selanjutnya Undangundang tersebut mengatur mengenai keberadaan organisasi pemerintahan yang berada di desa. Kuntuk keedepannya diharapkan agar mampu melakukan proses pembangunan di daerahnya masing-masing dengan mengatur dan mengurus sendiri rumah tangganya. Salah satu hal mendasar yang menjadi urusan pemerintahan desa adalah urusan yang menjadi kewenangan kabupaten/kota yang diserahkan pengaturannya kepada desa menurut Undang-Undang Nomor 72 Tahun 2005.

Pembangunan desa merupakan salah satu urusan yang menjadi kewenangan desa. Sebagai implikasi dari penyelanggaraan pembangunan tersebut, tentu saja akan membutuhkan pembiayaan atau sumber-sumber penerimaan desa. Salah satu sumber penerimaan desa yaitu dana perimbangan keuangan pusat dan daerah yang diterima oleh kabupaten/kota yang dalam pembagiannya untuk setiap desa. Dana desa adalah dana yang bersumber dari Anggaran Pendapatan dan 
Belanja Negara (APBN) yang diperuntukan bagi desa yang ditransfer melalui anggaran belanja daerah kabupaten/kota. Dana ini digunakan untuk membiayai penyelenggaraan pemerintahan, pelaksana pembangunan, pembinaan kemasyarakatan dan pemberdayaan masyarakat desa. Dana desa dialokasikan dari APBN berdasarkan Pasal 72 Ayat 1 Huruf b UU No 6 tahun 2004 tentang Desa.

Berdasarkan latar belakang permasalahan diatas, maka adapaun rumusan masalah yang dirumuskan yaitu apa pengertian dari dana desa, bagaimana cara dana desa di kelola oleh pemerintah desa, dan bagaimana pengaruh sistem pengelolaan dana desa terhadap laporan keuangan Desa.

\section{Metode Penelitian}

\subsection{Metode Penemuan Data}

Pembuatan Mini Riset ini mengggunakan metode sebagai berikut:

1. Metode Wawancara

Metode ini merupakan suatu cara memperoleh keterangan- keterangan atau pendapat-pendapat secara lisan dari beberapa responden

2. Metode Observasi

Metode ini merupakan metode pengumpulan data yang menggunakan pengamatan terhadap objek penelitian. Observasi dilakukan secara langsung atau secara tidak langsung. Dalam hal ini penulis menggunakan observasi secara tidak langsung dan mengamati secara tidak langsung ke tempat observasi.

\subsection{Metode Analisis Data}

Metode yang digunakan dalam penyusunan mini riset ini adalah Metode Kualitatif. Dimana metode kualitatif ini merupakan metode yang digunakan menggambarkan keadaan yang sebenarnya berdasarkan atas data yang diperoleh, sehingga dengan metode ini akan diperoleh, sehingga dengan metode ini akan diperoleh gambaran secara umum mengenai kejadian atau peristiwa yang menjadi objek penelitian.

Data Wawancara
Nama Responden
Pekerjaan
Alamat
: I Made Mudastra
: Kepala Desa
: Br. Cau Tua Marga Tabanan Bali

Wawancara ini dilakukan pada hari Sabtu, 5 Mei 2018 di rumah Bapak Made Mudastra di Banjar Cau Tua. Menurut penuturan beliau Desa Tua terdiri dari 3 banjar adat yaitu Banjar Cau, Banjar Tua dan Banjar Bayan. Pada awalnya pencatatan di Kantor Desa Tua menggunakan pencatatan berbasis kas, yaitu apabila terjadi transaksi yang mengeluarkan atau menerima kas baru akan dicatat. Misalnya proyek pembetonan jalan di daerah pesawahan Kelaci yang menggunakan anggaran dana desa, pembelian bahan baku seperti semen, pasir dan lain sebagainya akan dibayarkan secara tunai kepada toko dan baru akan dicatat dipembukuan kas keluar desa. Selain itu menurut beliau dahulu sistem pencatatan awal digunakan di buku memo yang berukuran besar agar dapat mencatat pengeluaran dan pemasukan dalam kurun waktu satu bulan kemudian akan dicatat kembali ke komputer sebagai penyimpanan data permanen. Setelah adanya perubahan pencatatan akuntansi dari basis kas menuju akrual hal ini cukup sulit dirasakan oleh staf maupun karyawan di Kantor Desa Tua hal ini disebabkan minimnya pelatihan dan sosialisasi dari Pemerintah Kabupaten dalam hal menerapkan basis kas menuju basis akrual. Sehingga pada bulan pertama terjadi banyak kesalahan dan koreksi dari pihak terkait, selain itu kendala yang dirasakan adalah pendidikan dari staf dan karyawan di Kantor Desa Tua minimal adalah pendidikan SMA/SMK sederajat, yang tentunya pada jaman mereka mengenyam pendidikan masih minim dalam pembelajaran akuntansi. 
Sehingga para staf dan karyawan di Kantor Desa Tua diharapkan dapat mempelajari pencatatan akuntansi yang berbasis kas menuju akrual agar dalam penyusunan laporan keuangan dapat meminimalisir koreksi dari pihak terkait.

Menurut beliau pernah dilaksakan pelatihan atau Bintek oleh Pemerintah Kabupaten Tabanan khususnya di kecamatan Marga pada Bulan Desember 2017 yang mewajibkan agar staf dan karyawan yang menangani urusan tentang proyek dan berurusan dengan aliran kas masuk dan kas keluar diharapkan dapat mengikuti pelatihan yang diselenggarakan oleh Pemerintah Kabupaten Tabanan, hal ini diharapkan dapat membantu dalam penyusunan laporan keuangan dari Desa, selain itu dapat menggambarkan posisi keuangan desa secara tepat dan akurat. Pelatihan Bintek ini dilaksakan selama 3 hari yang diikuti oleh 10 orang staf dan karyawan dari Desa Tua. Dengan adanya bintek yang dilakukan dapat sedikit mempermudah dalam penyusunan laporan keuangan Desa Tua. Menurut Beliau kelebihan dari pencatatan dari basis kas menuju akrual ini adalah dapat memberikan gambaran secara jelas tentang posisi keuangan dan mencatat semua transaksi baik yang telah mengeluarkan atau menerima kas dan belum menerima dan mengeluarkan kas.

Adapun pada saat ini proyek yang masih berjalan salah satunya adalah pembenahan kantor desa karena kondisi kantor desa yang terdahulu sedikit bermasalah seperti masalah kebocoran atap apabila hujan dan banyaknya berkas yang belum tersusun rapi karena infrastruktur seperti rak kurang memadai dan tempat yang sempit dalam menyimpan data-data maupun dokumen-dokumen yang ingin disimpan. Lamanya proses dalam pembenahan kantor desa ini dapat dikatakan cukup lama sekitar 7 bulan lamanya karena kantor desa ini direncanakan akan bertingkat 2 agar dapat lebih memiliki ruang dalam melakukan aktivitas pelayanan kepada masyarakat. Pada saat wawancara dilaksanakan, kantor desa Tua masih dalam tahap pengerjaan, sehingga kami sebagai penulis tidak dapat mendokumentasikan penelitian di kantor desa karena ditutupi oleh material bahan bangunan sehingga menjadi kendala penulis dalam hal dokumentasi dan selain itu belum sempat meminta foto bersama dengan kepala desa karena saat kami melakukan wawancara, kepala desakedatang tamu penting ke rumah bapak kepala desa, sehingga kami para penulis harus mengakhiri wawancara

Data Wawancara
Nama Responden
: I Made Mudastra
Pekerjaan
Alamat
: Kepala Desa
: Br. Cau Tua Marga Tabanan Bali

Wawancara ini dilakukan pada hari Sabtu, 5 Mei 2018 di rumah Bapak I Made Mudastra di Banjar Cau Tua. Menurut penuturan beliau Desa Tua terdiri dari 3 banjar adat yaitu Banjar Cau, Banjar Tua dan Banjar Bayan. Pada awalnya pencatatan di Kantor Desa Tua menggunakan pencatatan berbasis kas, yaitu apabila terjadi transaksi yang mengeluarkan atau menerima kas baru akan dicatat. Misalnya proyek pembetonan jalan di daerah pesawahan Kelaci yang menggunakan anggaran dana desa, pembelian bahan baku seperti semen, pasir dan lain sebagainya akan dibayarkan secara tunai kepada toko dan baru akan dicatat dipembukuan kas keluar desa. Selain itu menurut beliau dahulu sistem pencatatan awal digunakan di buku memo yang berukuran besar agar dapat mencatat pengeluaran dan pemasukan dalam kurun waktu satu bulan kemudian akan dicatat kembali ke komputer sebagai penyimpanan data permanen. Setelah adanya perubahan pencatatan akuntansi dari basis kas menuju akrual hal ini cukup sulit dirasakan oleh staf maupun karyawan di Kantor Desa Tua hal ini disebabkan minimnya pelatihan dan sosialisasi dari Pemerintah Kabupaten dalam hal menerapkan basis kas menuju basis akrual. Sehingga pada bulan pertama terjadi banyak kesalahan dan koreksi dari pihak terkait, selain itu kendala yang dirasakan adalah pendidikan dari staf dan karyawan di Kantor Desa Tua minimal 
adalah pendidikan SMA/SMK sederajat, yang tentunya pada jaman mereka mengenyam pendidikan masih minim dalam pembelajaran akuntansi. Sehingga para staf dan karyawan di Kantor Desa Tua diharapkan dapat mempelajari pencatatan akuntansi yang berbasis kas menuju akrual agar dalam penyusunan laporan keuangan dapat meminimalisir koreksi dari pihak terkait.

Menurut beliau pernah dilaksakan pelatihan atau Bintek oleh Pemerintah Kabupaten Tabanan khususnya di kecamatan Marga pada Bulan Desember 2017 yang mewajibkan agar staf dan karyawan yang menangani urusan tentang proyek dan berurusan dengan aliran kas masuk dan kas keluar diharapkan dapat mengikuti pelatihan yang diselenggarakan oleh Pemerintah Kabupaten Tabanan, hal ini diharapkan dapat membantu dalam penyusunan laporan keuangan dari Desa, selain itu dapat menggambarkan posisi keuangan desa secara tepat dan akurat. Pelatihan Bintek ini dilaksakan selama 3 hari yang diikuti oleh 10 orang staf dan karyawan dari Desa Tua. Dengan adanya bintek yang dilakukan dapat sedikit mempermudah dalam penyusunan laporan keuangan Desa Tua. Menurut Beliau kelebihan dari pencatatan dari basis kas menuju akrual ini adalah dapat memberikan gambaran secara jelas tentang posisi keuangan dan mencatat semua transaksi baik yang telah mengeluarkan atau menerima kas dan belum menerima dan mengeluarkan kas.

Adapun pada saat ini proyek yang masih berjalan salah satunya adalah pembenahan kantor desa karena kondisi kantor desa yang terdahulu sedikit bermasalah seperti masalah kebocoran atap apabila hujan dan banyaknya berkas yang belum tersusun rapi karena infrastruktur seperti rak kurang memadai dan tempat yang sempit dalam menyimpan data-data maupun dokumendokumen yang ingin disimpan. Lamanya proses dalam pembenahan kantor desa ini dapat dikatakan cukup lama sekitar 7 bulan lamanya karena kantor desa ini direncanakan akan bertingkat 2 agar dapat lebih memiliki ruang dalam melakukan aktivitas pelayanan kepada masyarakat. Pada saat wawancara dilaksanakan, kantor desa Tua masih dalam tahap pengerjaan, sehingga kami sebagai penulis tidak dapat mendokumentasikan penelitian di kantor desa karena ditutupi oleh material bahan bangunan sehingga menjadi kendala penulis dalam hal dokumentasi dan selain itu belum sempat meminta foto bersama dengan kepala desa karena saat kami melakukan wawancara, kepala desa kedatang tamu penting ke rumah bapak kepala desa, sehingga kami para penulis harus mengakhiri wawancara dengan beliau.

\section{Hasil dan Pembahasan}

\subsection{Pengertian Dana Desa}

Dana Desa adalah dana yang bersumber dari Anggaran Pendapatan dan Belanja Negara yang diperuntukkan bagi Desa dan Desa Adat yang ditransfer melalui Anggaran Pendapatan dan Belanja Daerah kabupaten/kota dan digunakan untuk membiayai penyelenggaran pemerintahan, pembangunan, serta pemberdayaan masyarakat, dan kemasyarakatan. Fokus penting dari penyaluran dana ini lebih terkait pada implementasi pengalokasian Dana Desa agar bisa sesempurna gagasan para inisiatornya.

Skenario awal Dana Desa ini diberikan dengan mengganti program pemerintah yang dulunya disebut PNPM, namun dengan berlakunya Dana Desa ini, dapat menutup kesempatan beberapa pihak asing untuk menyalurkan dana ke daerah di Indonesia dengan program-program yang sebenarnya juga dapat menjadi pemicu pembangunan daerah. Sesuai dengan amanat Undang-Undang Nomor Tahun 2014 tentang Desa, Pemerintah mengalokasikan Dana Desa, melalui mekanisme transfer kepada Kabupaten/Kota. Berdasarkan alokasi Dana tersebut, maka tiap Kabupaten/Kota mengalokasikannya ke pada setiap desa berdasarkan jumlah desa dengan memperhatikan jumlah penduduk (30\%), luas wilayah (20\%), dan angka kemiskinan (50\%). Hasil 
perhitungan tersebut disesuaikan juga dengan tingkat kesulitan geografis masing-masing desa.

\subsection{Cara Dana Desa dikelola Oleh Pemerintah Desa}

Pengelolaan keuangan desa adalah keseuruhan kegiatan yang meliputi perencanaan, pelaksanaan, penatausahaan, pelaporan, dan pertanggungjawaban keuangan desa. Penyelenggaraan kewenangan desa berdasarkan hak asal usul dan kewenangan lokal berskala desa didanai oleh ABPDesa. Penyelenggaraan kewenangan lokal berskala desa selain dinai oleh APBDesa, juga dapat didanai oleh anggaran pendapatan dan belanja negara dan anggaran pendapatan dan belanja daerah. Penyelenggaraan kewenangan desa ditugaskan oleh pemerintah didanai oleh anggaran pendapatan dan belanja negara. Dana anggaran pendapatan dan belanja negara dialokasikan pada bagian anggaran kementrian/lembaga dan disalurkan melalui satuan kerja perangkat daerah kabupaten/kota. Penyelenggaraan kewenangan desa yang ditugaskan oleh pemerintah daerah didanai oleh anggaran pendapatan dan belanja daerah. Seluruh pendapatan desa diterima dan disalurkan melalui rekening kas Desa dan penggunaanya ditetapkan dalam APB Desa. Pencairan dana dalam rekening kas Desa ditandatangani oleh kepala Desa dan Bendahara Desa. Kepala desa adalah pemegang kekuasaan pengelolaan keuangan desa. Dalam melaksanakan kekuasaan pengelolaan keuangan desa, kepala desa menguasakan sebagian kekuasaannya kepada perangkat desa.

Dasar hukum pengelolaan keuangan desa tertuang pada Permendagri Nomor 113 tahun 2014 tentang Pengelolaan Keuangan Desa. Pengelolaan dana desa juga perlu memperhatikan beberapa asas yang ada yaitu Trasnparan; Akuntabel; Partisipatif; Tertib dan DisiplinAnggaran. Jangka waktu pengelolaan keuangan desa itu satu tahun anggaran terhitung mulai dari 1 Januari sampai 31 Desember tahun berjalan. Renacana keuangan tahunan pemerintah desa dituangkan dalam Anggaran Pendapatan dan Belanja Desa atau disingkat menjadi ABPDesa.

Pengelolaan keuangan desa tentunya berpengaruh alam cara pengelolaan dana desa yang diterima oleh setiap masing-masing desa. Terdapat beberapa sumber penerimaan desa, salah satunya alokasi Dana desa merupakan bagian dari daa perimbangan yang diterima oleh kabupaten/kota, besranya minimal $10 \%$ dari dana perimbangan setelah dikurangi dengan dana Alokasi Khusus. Alokasi dana desa berbeda dengan dana desa. Jika dana desa bersumber dari APBN maka alokasi dana desa bersumber dari ABPD.

Dalam pelaksanaan pengelolaan dana desa peran serta masyarakat menjadi hal yang penting terutama dalam proses pengambilan keputusan dan pelaksanaan kegiatan yang menyangkut kebutuhan masyarakat desa. Selain itu, diperlukan adanya kerjasama yang baik antara aparatur desa dengan masyarakat dalam setiap tahapan-tahapan pengelolaan alokasi dana desa. Jika hal tersebut berjalanan dengan baik maka besar kemungkinan masyarakat dapat lebih mengembangkan diri untuk mencapai kemajuan program yang direncanakan.

\subsection{Pengaruh Sistem Pengelolaan Dana Desa Terhadap Laporan \\ Keuangan Desa}

Dengan adanya dana desa tentu memengaruhi pengelolaan keuangan desa dan berujung terhadap laporan keuangan. Karena desa merupakan salah satu organisasi pulik yang melayani kepentingan orang banyak, segala bentuk dana yang diterima tentu harus dipertanggungjawabkan, salah satu bentuk pertanggungjawaban adalah dengan adanya laporan keuangan. Laporan keuanga merupakan bentuk informasi yang memuat nominal nominal uanga yang telah digunakan atau dibelanjakan dan juga jumalah penerimaan yang diterima oleh desa tersebut.

Pada kesempatan kali ini kami tertarik untuk melakukan riset terhadap pengaruh adanya dana desa terhadap laporan keuangan yang ada di Desa Tua Marga Tabanan. Cukup sulit memang karena pihak Desa tidak memperbolehkan 
kami untuk melihat bagaimana laporan keuangan yang telah dibuat oleh aparatur desa disana setelah beberapa tahun dana desa dijalankan.

Namun menurut penuturan narasumber kami yang sekaligus merupakan kepala desa di desa Tua. Beliau menuturkan bahwa pada awalnya mereka menggunakan sistem akuntansi berbasis kas, mereka menulis pengeluaran yang terjadi di buku kas folio. Setelah itu data tersebut baru kemudian di input ke komputer untuk dijadikan sebagai data soft. Dengan adanya perubahan sistem pencacatan akuntansi yang mengharuskan menggunakkan basis akrual tentu hal itu menjadi sebuah hambatan bagi desa tersebut. Beliau juga menuturkan minimnya pelatihan dan sosialisasi dari pemerintah kabupaten/kota sehingga pada pelaksanaan bulan pertama terjadi beberapa kesalahan pada laporan keuangan, dan kemudian dikoreksi oleh pihak terkait. Selain itu juga minimnya tingkat pengetahuan dan pendidikan staf terkait juga menjadi kendala bagi mereka. Karena terkadang staf - staf yang bekerja merupakan orang yang dipandang memiliki pengaruhnya yang kuat terlepas dari seberapa tinggi pendidikan mereka.

Narasumber juga menuturkan, untuk mengatasi hal kurangnya sosialisasi dari pihak pemerintah kabupaten/kota, dilakukanlah sebuah pelatihan atau disebut juga dengan Bintek, untuk menaggulangi masalah yang ada terhadap staf - staf yang menaungi hal tersebut. Pelatihan tersebut dilaksanakan selama 3 hari. Dengan diadakannya pelatihan ini diharapkan dapat memberikan pemahaman kepada para staf yang masih belum memahami betul mengenai sistem pencatatan dengan basis akrual, namun setelah diadakannya pelatihan ini pun para staf masih merasa kurang memahami akan sistem pencatatan ini. Berdasarkan pemaparan yang diberikan oleh narasumber mengenai jalannya pelatihan atau yang disebut Bintek tersebut, kami menyadari bahwa yang menyebabkan para staf di kelurahan Desa Tua adalah ketidakseimbangan antara tenaga pelatih dengan peserta pelatihan serta kondisi pelatihan yang kurang memadai.

Menurut pemaparan beliau pelatihan atau Bintek ini tidak hanya diikuti oleh satu kelurahan saja. ketidakseimbangan antara tenaga pelatih dengan peserta pelatihan menyebabkan kegiatan pelatihan atau yang disebut Bintek tersebut menjadi tidak efektif, dimana jumlah peserta yang mengikuti pelatihan tersebut lebih banyak daripada tenaga pelatih yang ada. Selain itu kondisi pelatihan yang kurang memadai juga menjadi faktor yang menyebabkan para peserta pelatihan masih juga belum memahami pencatatan basis akrual ini. Kondisi yang dimaksud bukan dari segi kelengkapan sarana dan prasarana kegiatan pelatihan melainkan tidak kondusifnya suasana pelatihan yang dilakukan pada saat itu. Sehingga tujuan dari diadakannya pelatihan ini yaitu untuk memberikan pemahaman megenai pencatatan dengan basis akrual dan pengelolaan keuangan yang baik dan benar masih belum tercapai secara maksimal. Seperti yang sudah kami paparkan sebelumnya mengenai pengelolaan keuangan. Pengelolaan keuangan terdiri dari:

- Perencanaan

- Pelaksanaan

- Penatausahaan

- Pelaporan

- Pertanggungjawaban keuangan desa Kepala desa selaku pihak yang berwenang untuk menyetujui suatu perencanaan pengeluarann dana ataupun kegiatan perlu memperhatikan baik baik rancangan rencana tersebut sebelum disetujui, perlu dilakuknnya pengkajian juga. Dan dengan adanya dana desa dan perubahan basis pencatatan bukan berarti menjadi pengambat untuk desa tersebut dalam pembuatan laporan keuangan melainkan ini adalah sebuah tantangan yang harus dilalui untuk menciptakan pengelolaan dana desa yang lebih baik dan benar, sehingga dengan adanya pengelolaan yang baik dan benar maka hal ini tentunya akan memberikan dampak yang baik pula tidak hanya pada kinerja dari para staf tapi 
juga akan memberikan dampak kepada perkembangan dan kemajuan desa itu sendiri.

Pelaksanaan dari penggunaan dana desa harus diawasi dan diarahkan untuk meminimalisir terjadinya kesalahan serta untuk mencegah terjadinya kecurangan yang mungkin dilakukan oleh para staf yang tidak bertanggungjawab. Adanya perubahan pada basis pencatatan ini diharapkan mampu memberikan manfaat yang positif dari segi pelaksanaan.

Pengelolaan dana desa yang baik juga tidak luput dari penatausahaan yang baik. Penata usahaan merupakan rangakaian kegiatan yang meliputi pembukuan, inventarisasi, dan pelaporan baarang milik Negara/Daerah sesuai dengan ketentuan Peraturan Perundang-undangan.

Pelaporan yang baik adalah pelaporan yang mampu memberikan informasi yang jelas. Dengan adanya perubahan sistem pencacatan akuntansi yang mengharuskan menggunakkan basis akrual hal ini tentunya juga akan berpengaruh pada kualitas pelaporan pengeloalaan dana desa. Pada pencatatan basis akrual transaksi dicatat pada saat terjadinya, meskipun belum menerima ataupun mengeluarkan kas. Sehingga akan meningkatkan pelaporan keuangan dari dana desa yang digunakan.

\section{Simpulan dan Saran}

\subsection{Simpulan}

Berdasarkan pembahasan yang telah dipaparkan pada bab sebelumnya dapat disimpulkan sebagai berikut.

1. Dana Desa adalah dana yang bersumber dari Anggaran Pendapatan dan Belanja Negara yang diperuntukkan bagi Desa dan Desa Adat yang ditransfer melalui Anggaran Pendapatan dan Belanja Daerah kabupaten/kota dan digunakan untuk membiayai penyelenggaran pemerintahan, pembangunan, serta pemberdayaan masyarakat, dan kemasyarakatan.

2. Dana desa dikelola oleh pemerintah desa berdasarkan pada Permendagri Nomor 113 tahun 2014 tentang Pengelolaan Keuangan Desa. Penyelenggaraan kewenangan desa yang ditugaskan oleh pemerintah daerah didanai oleh anggaran pendapatan dan belanja daerah. Seluruh pendapatan desa diterima dan disalurkan melalui rekening kas Desa dan penggunaanya ditetapkan dalam APB Desa. Pencairan dana dalam rekening kas Desa ditandatangani oleh kepala Desa dan Bendahara Desa.

3. Sistem pengelolaan dana desa akan berpengaruh pada laporan keuangan desa. Dalam hal ini system pengelolaan dana desa pada Desa Tua Kabupaten Tabanan yang mulai beralih dari basis kas menuju basis akrual. Sistem pengelolaan dana desa pada Desa Tua dengan menggunakan basis kas masih banyak terdapat masalah-masalah pada laporan keuangannya. Dengan beralih menuju basis akrual diharapkan masalah-masalah tersebut dapat teratasi.

\subsection{Saran}

Saran yang dapat kami berikan mengenai pengelolaan dana desa di Desa Tua Kabupaten Tabanan yaitu dengan meningkatkan kualitas para staf yang menangani pengelolaan dana desa baik melalui pelatihan maupun dengan mengganti atau merombak para staf atau anggota yang tidak berkompeten sehingga pengelolaan dana desa pada Desa Tua Kabupaten Tabanan dapat dikelola dengan lebih baik lagi. 


\section{Daftar Pustaka}

https://id.wikipedia.org/wiki/Desa $\quad \underline{\text { https://www.kemenkeu.go.id/media/6749/buku- }}$ pintar-dana- desa.pdf

https://bppk.kemenkeu.go.id/id/publikasi/artikel/147-artikel-anggaran-dan perbendaharaan/20477-pengelolaan-keuangan-desa-sistem-dan-prosedur pertanggungjawaban-keuangan-desa

http://www.hukumonline.com/klinik/detail/lt57c9664e65249/pengalokasian--penyaluran-dan-pengawasan-dana-desa

http://www.negeripesona.com/2017/05/pengertian-desa-menurut-undang-undang.html 
Jurnal Ilmiah Akuntansi dan Humanika, Vol. 7 No. 3, Desember 2017

ISSN: 2599-2651 